\title{
The Talmudic Tradition in Contemporary British-Jewish Fiction: Silence versus Talking
}

\begin{abstract}
The purpose of this article is to demonstrate that contemporary British-Jewish fiction turns away from silence which is understood as a means of preventing problems in the community and that it depicts this kind of silence as harmful to family bonds. Instead, as I shall argue, recent British novels draw from the long-established tradition of Talmudic discussion and describe it as a method of solving intergenerational conflicts. Such an approach is visible in Disobedience by Naomi Alderman, The Marrying of Chani Kaufman by Eve Harris, When We Were Bad by Charlotte Mendelson, and The Innocents by Francesca Segal.
\end{abstract}

Keywords: British Jews, Talmud, silence, discussion, family.

\section{The uniting force of the Talmud}

The Jewish Diaspora has always been bound together by the Talmud, the holy text of Judaism. As a core of Jewish culture, the Talmud has been consulted by religious Jews when they were searching for the answers to subjects regarding lifestyle and, above all, religion. It consists of two parts: Mishnah and Gemara (Jacobs 2008a: 2-3). Mishnah is the Oral Law that, as it is believed, was given to Moses on Mount Sinai, passed down from generation to generation and written down in 200 CE (Jacobs 2008a: 1-2). Gemara, written around 500 CE, consists of writings that develop the thoughts from Mishnah (Jacobs 2008a: 3). The Talmud has bound Jewish people in the Dispersion for more than 2000 years. Not only has the Talmud passed down knowledge of the laws of Judaism, but also, as Shwarzer notes, its organization mirrored the architectural structure of the Temple, being thus a portable version of the destroyed place of worship (Schwartzer 2001: 474487). However, the Talmud has never been approached as a fossilized list of religious rules. Jacobs points to the fact that it "constitutes reasoning processes which have received the most careful study on the part of generations of Jewish scholars and have contributed more to the shaping of the Jewish mind than any other factor" (Jacobs 2008a: 1). The dialogue on the implementation of Talmudic texts has been the central element of Jewish education for ages. 


\section{Havruta: a discussion leading to knowledge}

The discussions between students and teachers tend to develop into heated disputes. It is the students who ask problematic questions who are valued most (Jacobs 2008b: 7). Moreover, since World War I, havruta, a traditional method of analyzing and interpreting fragments of the Talmud in groups and especially in pairs has become the dominant approach to this text (Arbor 2014: 213). Shwartz and Katz observe that havruta is considered the best method of learning as it seems to strengthen the sense of community and to protect from embarrassment, a feeling rarely absent in an individual study with a teacher, who tends to be on higher intellectual level than his student (Katz and Schwartz 1998: 317). A havruta partner does not have to be chosen by a Rabbi, sometimes a student can do it individually. Nowadays, the Talmud can be studied in havruta not only in traditional Talmudic schools but also via the Internet or with friends at home. Moreover, Talmudic disputes are present in a vast body of commentaries written by generations of Rabbis. The infinity of intergenerational disputes on the pages of Talmudic literature seems to reflect the Jewish belief in the infinity of the Divine Word (Salfati 2009: 12). In other words, according to Judaism, no question exists that would not find its answer in the Talmud.

Interestingly, this model of learning finds its counterpart in the everyday life of many Jewish families. It includes both the havruta partners' and the teacher-student relation. According to Amos Oz, "While scholarship matters enormously, family matters even more. These two mainstays tend to overlap. Fathers, mothers, teachers. Sons, daughters, students. Text, question, dispute" (Oz 2007a: X). He observes that, just like the students in Talmudic schools challenge their teachers, in the Talmud, "sons, biological or metaphorical, constantly challenge their fathers" (Oz 2007b: 36). According to the writer, "Ancient Hebrew texts are continually engaged with two crucial pairings: parent and child, teacher and pupil" (Oz 2007b: 6). In other words, fathers may be identified as rabbis, and their children as their students. The teacher's duty is to pass on the Judaic ways of living, but he is meant also to address the challenging questions and doubts of the next generation by means of logic together with arguments that can be derived from the scripture.

\section{The spirit of havruta in contemporary British-Jewish novels}

Unfortunately, this centuries-old spirit of creative dispute has disappeared in the majority of contemporary orthodox Jewish communities (Oz 2007b: 35). Curiously though, recent British-Jewish novels draw from the tradition of Talmudic arguments in families. Such an interest is clearly visible in Disobedience by Naomi Alderman and The Marrying of Chani Kaufman by Eve Harris. A distinct echo of this preoccupation is also detected in two other novels: When We Were Bad by Charlotte Mendelson and The Innocents by Francesca Segal. Each of these books opens with a scene in a synagogue that symbolically places the texts in Judaic tradition and each of them deals with the subject of British-Jewish families' dilemmas regarding lifestyle and religion.

British Jews, an amalgam of two distinct cultures, are a marginal but an important minority in the Isles. Ruth Gilbert, one of the leading experts on contemporary British-Jewish literature, 
points to the fact that "[u]ntil quite recently there has been a pervading sense that American[Jewish] writing has somewhat dominated the literary and cultural agenda" (Gilbert 2008: 397). However, as she notes, "current studies are increasingly recognising the need to untangle the British experience from the American and the wider European perspectives and focus on the particularity of the Anglo-Jewish context" (Gilbert 2008: 397, italics in the original).

Most importantly, in contrast to reticent Englishmen, Jews, for a long time have been stereotypically associated with talkativeness, and consequently have perceived themselves as "a category error" (Gilbert 2008: 398). Yet, the negative perception of the propensity to talk has recently started to give way to an opposite tendency. The purpose of this essay is to demonstrate that recent British-Jewish fiction turns away from silence which is understood as a means of preventing problems in community, that it depicts this kind of silence as harmful to family bonds and that instead, it turns to discussion as a method of solving intergenerational conflicts.

\section{Overcoming differences}

As Cheyette observes, "Most recent British-Jewish writers are not merely unapologetic in their Jewishness but can be characterized as Jews 'with attitude' who disrupt all conventions" (qtd. in Gilbert 2008: 402). Naomi Alderman certainly belongs to this group. In her novel with a very telling title, Disobedience, she presents a story of an orthodox Jewish community stirred by the arrival of a Rabbi's daughter, Ronit, who years before decided to move to New York and pursue a secular life. After a long time of absence, she flies to London for her father's funeral. During the event, she meets her childhood sweetheart, Esti, who is now married to a future Rabbi, Dovid. The romantic feeling between Ronit and Esti develops once again.

Ronit's sudden arrival provokes a number of reflections on Ronit's, Esti's and Dovid's part. All three of them approach the questions they are interested in by means of Talmudic discourse. Each chapter is introduced by a quotation from the Talmud and followed by musings associated with it. The first of them always comes from the narrator. The following, depending on the chapter, is either from Ronit, Dovid or from Esti. Together, united in the dialogue that has as its purpose to answer their doubts, they constitute a havruta group. The subjects they explore are interconnected and aim at answering one major question, namely: What is happiness?

The question is embedded in long elaborations on the opposition of silence versus talking, the graveness of the former and the regenerating quality of the latter. According to Ronit's father and for a long time also Dovid, certain things are better left unseen and untold. Such a taboo subject is, among others, Dovid's illness, which manifests itself through sudden attacks of panic when he is facing stressful situations. Ronit, on the other hand, does not ever hesitate to say what she thinks. She even colors the truth to make it more shocking for those members of the orthodox community whom she does not particularly like. When asked by them if she is in any relationship with a man, she answers that she has a female partner, and that they intend to organize a commitment ceremony and have children with some gay couple (Alderman 2007: 98-99). Surprisingly, this little provocation does not shock Dovid, but makes him smile (Alderman 2007: 99). Though he knows 
that Ronit is not serious, he is far from being appalled by her behaviour, it simply amuses him. This reaction is significant as it shows that he is not critical of her talkativeness on subjects controversial for ultra-orthodox Jews.

As Ronit's therapist rightly observes, "Silence is not power. It's not strength. Silence is the means by which the weak remain weak and the strong remain strong. Silence is a method of oppression" (Alderman 2007: 153). As the book progresses, the readers witness a gradual change in Dovid's behaviour. From a man who refuses to address things he does not know how to cope with to an assertive Rabbi who decides to give voice to his wife during the funeral of Ronit's father (e.g. Alderman 2007: 48, 148). Quite possibly, it was the will to change his behaviour that made his wife decide to stay with him, and for Ronit not to break off her contact with the community like she once did. As the following fragment discloses, "Ronit thought she was running away from God, but in fact she was fleeing from silence" (Alderman 2007: 221).

Talking is also closely connected to the notion of gossip, which is heavily criticized in chapter seven of the novel. It opens with a fragment about the danger of engaging in conversations with women, which leads to men neglecting their duty to study the Talmud (Alderman 2007: 122). The narrator recounts how the Hendon women, when shopping, gossip about Ronit's, Esti's and Dovid's private life (Alderman 2007: 124-125). Significantly, what follows directly after the mentioned fragment is a description of Ronit's dream about seagulls that stand for the members of the local Jewish community who constantly observe and analyze her movements:

That night I dreamed of the seagulls of Hendon, of the extreme sharpness of their beaks and the flexing of their claws. Of the way they set their heads on one side and look at you with one, unfathomable beady eye. It was a Tippi Hedren sort of dream, of running away from flocks of seagulls, except that these birds weren't doing anything, not attacking or coming down the chimney or cracking glass. They were just looking. (Alderman 2007: 133, italics as in the original).

The novel thus points to the need for discussion, the lack of which leads to breaking relations with other people, in other words, to separation. According to both the narrator and Dovid, because it was God who created all separations, they must be essentially good (Alderman 2007: 4246). They take many forms, such as kosher and unkosher food, or different spaces for men and women in synagogues. The musings on the subject of separation in chapter four open with a Talmudic fragment claiming it is better to be a man than a woman (Alderman 2007: 58). According to the narrator, such a statement is understandable as two people cannot be in possession of one crown (Alderman 2007: 58-59). For Esti, there is also the separation from Ronit, and for Ronit, her cutting herself off from her father.

However, if all these arrangements are good, why do both Ronit and Esti feel that they are missing something? Esti symbolically communicates her longing for her childhood friend by an act of mixing kosher and unkosher ingredients (Alderman 2007: 46-47). As for Ronit, it is her therapist who suggests she misses her father, though she may not be aware of it (Alderman 2007: 51). Their doubts 
indicate that it is necessary to depart from uncritical and silent conformity to rules maladjusted to the changing needs of individual members of the community. This is especially visible in the story of a battle between Jacob and an angel. As the narrator comments: "But let us not deny that, of the many things He asks, some few may perhaps seem to us not only difficult but also unjust, unfair. Wrong. And, in these moments, let us never doubt that we too have a voice within us to speak, that we too, like Abraham and Moses, may argue with the Lord. It is our right" (Alderman 2007: 234).

Undoubtedly, all of the three, Ronit, Esti and Dovid, approve of such an interpretation of this biblical passage. Each of them is a rebel. In the synagogue, during Ronit's father's funeral, Dovid decides to stand in the ladies' gallery, which is behaviour the community is not accustomed to. He shocks them even more when he allows his wife to speak publicly about her sexuality. As for Ronit, she disobeys her father when she decides to stay in New York. Just as Dovid she cannot accept the previous Rabbi's attitude towards silence and neither can Esti. She says that words are important, but people should use them wisely: "Our words are powerful. Our words are real. This does not mean, however, that we should remain silent forever. Rather, we must measure our words. We must be sure that we use them, like the Almighty, to create and not to destroy" (Alderman 2007: 246).

The narrator draws attention to the fact that according to the Talmud, though the discussions humans engage in may be infinite and futile, they have been given free will and with it the right to disobey, not only other humans, but also God. Such a teaching is presented in one of the Talmudic stories elaborated on in the novel. It describes an argument between three prophets who cannot agree on one interpretation of a complicated point of law (Alderman 2007: 249-250). Even though God indicates the one who is right, they still hold to their own arguments (Alderman 2007: 250). According to the narrator, "We do not hear simply the pure voice of the Almighty as the angels do. We are not ruled by blind instinct like the beasts. Uniquely, we can listen to the commands of God, can understand them, yet can choose disobedience. It is this, and only this, which gives our obedience its value" (Alderman 2007: 213).

Ronit's, Esti's and Dovid's reflections and their cooperation in the quest for answers are reflected by the novel's arrangement which symbolically encourages discussion as opposed to destructive silence. It is worth mentioning Ruth Gilbert's point that "Lesbian narrative in this narrative signifies a challenge to traditional family structures that is potentially disruptive but, it is implied, also regenerative" (Gilbert 2008: 394-406). This regeneration is evident in the outcome of the discussion in the novel. The marriage of Esti and Dovid is not destroyed, despite Esti's lesbian affair with Ronit. The couple decide to continue on living together in an orthodox Jewish environment, raise their child in a family that promotes discussion and gives voice to everyone, no matter whether one is a woman, a man, a heterosexual or a homosexual.

\section{Modernizing an ultra-orthodox community}

The spirit of Talmudic discussion is also easily detected in Eve Harris's novel, The Marrying of Chani Kaufman. It opens with a citation from the Torah: "Therefore shall each man forsake his 
mother and father, and cling to his wife, and they shall become one flesh" (Gen 2:23, 24). The book's central theme is of Jewish marriage and divorce. The Marrying of Chani Kaufman asks questions about the extent of the parental influence on children, of how much of this influence should be approved of when the children leave home and have found their own orthodox Jewish families. It also puts in doubt the notion that it is possible to live a happy orthodox Jewish married life in contemporary times. However, most of, just as in the case of Disobedience, The Marrying of Chani Kaufmann argues that all these issues should be approached by means of intergenerational dialogue and discussions in havruta. At the same time, the book depicts the consequences of rejecting such a procedure and of turning to silence.

In contrast to Disobedience, this novel does not provide Talmudic quotations at the beginning of each chapter. Instead, there are numerous descriptions of orthodox Jewish religious rituals, such as ritual immersion in mikveh ${ }^{1}$, and other procedures before, during and after the ceremony of marriage. There are two major havruta pairs: Chani and Baruch, and the Rabbi and the Rebbetzin. Though both Chani and Baruch are religious Jews, they want to negotiate the obligations of married life in an ultra-orthodox community. Their present form is difficult to accept both for the Rabbetzin, Baruch and Chani. Nonetheless, Baruch's and Chani's dealing with the problem differs essentially from the one of the Rabbetzin and her husband. The first couple choose discussion, the second, despite the Rabbetzin's plights, stay on the path of silence and consequently separate.

The answer to the question on the viability of orthodox marriage in the twenty first century is therefore positive but only if critically approached by both future or present spouses. Moreover, the book suggests that the institution of orthodox marriage cannot escape certain modernisations. Answers regarding marriage that Chani asks are provided by the Rabbetzin, who is not allowed to encourage the girl to think critically. In turn, the new generation seek a modernised way of life, in which there would be fewer regulations and taboos, especially concerning their sexual life.

Chani and Baruch create a havruta and try to find answers together; this is what makes their relationship successful. On a more general level, the novel appears to suggest that if the Jewish ultra-orthodox communities refuse to critically rethink and negotiate their traditions, more and more of them will choose a secular life. This is exactly what Alderman pointed to in Disobedience.

According to $\mathrm{Oz}$, “The Talmud stipulated, and the Haggadah" later popularized, some family rules of discussion. It was a paradigm of intergenerational quizzing: youngsters ask questions and their elders reply" (Oz 2007b: 36). This practice of intergenerational discussion, as Alderman's and Harris's novels argue, is something that Jewish orthodox communities should turn back to as it may help to develop solutions to major doubts about the orthodox ways of living that the new generation is presently facing.

1 Mikveh is a "ritual bathing pool in which a person immerses himself as part of the transition to ritual purity" (wWw.chabad.org).

2 Haggadah is the "book that retells the story of the exodus, from which the Passover seder is conducted" (www.chabad.org). 


\section{From a goddess to a Rabbi}

When We Were Bad, although it tells a story of a less orthodox community than in Disobedience or The Marrying of Chani Kaufman, just as in case of these two books, it draws attention to the regenerative potential of discussion in inter-generational relations. One of the questions that the novel tries to answer is whether a female Rabbi, Claudia, should accept the controversial choice by her son, Adam, to marry a divorced woman. Even more importantly, it explores the question of the limits of the Rabbi's influence on the synagogue's members. The Rabbi's conflict with Adam makes it possible to answer this second, even more important question.

The two, Claudia and Adam, may be clearly identified as a teacher and a student. They do not, however, discuss a specific fragment of the Talmud but the Rabbi's belief that "As its senior rabbi herself has said, community, family, is the answer. Aren't they all lucky to be part of hers?" (Mendelson 2007: 9). Claudia has become the only one that should be listened to in the synagogue environment, somehow effacing the central figure of God that she is meant to represent. Described as an ancient statue, Claudia has the air of a goddess that should be worshipped: "[she] had sat up, slick dark hair like an otter, breasts and shoulders shining: too monumental to be beautiful but beautiful all the same" (Mendelson 2007: 7). With such a Rabbi, adored by all the members of the local community, the critical thinking and the spirit of discussion among them has been lost. Not only her son, but also other characters in the novel feel oppressed, as it may be easily sensed, above all, in the opening chapter of When We Were Bad (Mendelson 2007: 5-13).

Yet despite the fear of disobeying Claudia, Leo decides to develop his relationship with the woman he is in love with. Finally, the mother and the son reach a consensus:

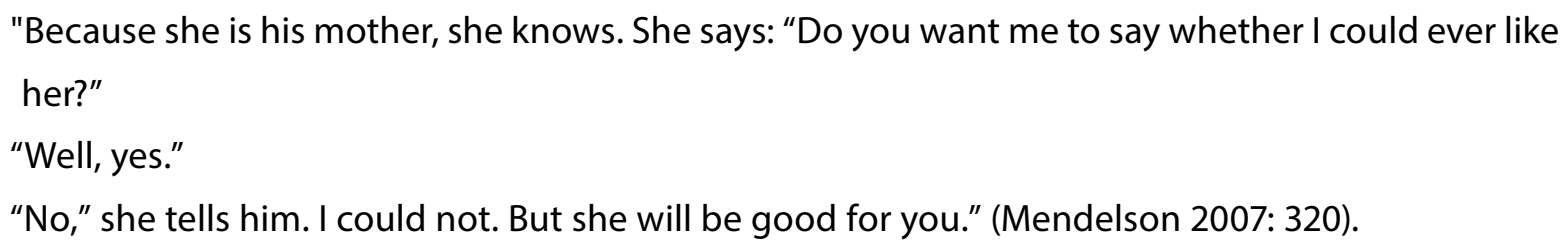

The fragment suggests that Claudia decides to accept her son's decision, which wouldn't have been possible if she refused to talk with her son. Moreover, and even more importantly, in the process of coming to terms with Adam's disobedience, Claudia changes her attitude towards all the members of the synagogue. From a godly figure, she becomes a human being. The intergenerational dialogue of the mother and the son brings fresh air to the whole community. The title itself suggests this shift. 'When we were bad' means 'before we became good'. It thus contrasts the past state of the community with the present one. The transition between the two happened as an aftermath of the dialogue and reconciliation of Claudia and Adam. Had they chosen silence, the situation both in the family and in the synagogue community would have continued to deteriorate. 


\section{The threat of omnipotence}

If Disobedience, The Marrying of Chani Kaufman and When We Were Bad all end in a positive tone showing a happy or partially happy denouement, The Innocents by Francesca Segal portraits the oppression that turning to silence creates. The dialogue in Segal's book had the potential to develop but did not, mostly due to the refusal to listen and to discuss by the head of the family, the "teacher". Though not a Rabbi but a businessman, Lawrence is the only person who should be truly obeyed in his family, which is very explicitly pointed to in the following fragment: "He was not stooping in apology - today, Lawrence looked like a patriarch. Tall and erect in the old black overcoat that Jaffa had brushed with extra care for the occasion, Lawrence had his arm around a zaftig and voluble wife he worshipped, a beautiful daughter beside him listening with respect and adoration, his prayer book in his hands as he read" (Segal 2013: 394, italics as in the original).

He gives the impression of being a loving, caring father who believes that one's family's wellbeing should be a priority for everyone. Yet, he is the one who decides how the lives of his relatives should appear, in which relationships they should engage in and in which not. His power over his daughter and her husband is symbolically depicted by Lawrence's taking photos of the couple during a family trip: "Together [Adam and Rachel], they turned to look up at the beaming Lawrence who extended his camera towards them, capturing for posterity the moment at which they arrived together, back on the dry land" (Segal 2013: 204); and during the ritual of Rachel's and Adam's son's circumcision:

Already in his tallit, Lawrence stood in the doorway, squinting at the dials of the camera that hung on a fraying leather strap around his neck, where it had been for almost every hour of the last eight days. Adam had increased the resolution on all the cameras in the family so that these first portraits could be reproduced in brilliant details, meters wide. Clear enough to preserve every nuance, every moment, every cell. Frowning in concentration Lawrence cupped his hand over the screen, anxious to be prepared. As Rachel and Adam approached, hand in hand, he looked up and Adam caught his eye. Lawrence smiled. (Segal 2013: 436, italics as in the original).

When his son in law, Adam, has an affair with a beautiful cousin, Ellie, and wonders whether or not to leave his wife, Lawrence, with the help of the family, expels Ellie from their environment. The family, which seems to be very warm and caring, is described as a jury who sentences Adam to a sense of guilt (Segal 2013: 391-397).

It should be noticed that the plot of the novel is very similar to the one of Disobedience. Both stories start with the return of a liberated American woman to an English Jewish community. In addition, each of these characters have an affair with a married man from this very environment and in both novels the neighbourhood presented oscillates around the central male figure who is at the same time a father figure. Quite significantly, Adam treats Lawrence as a father, his biological one having died when Adam was still a child. Nonetheless, in contrast to Disobedience, the dialogue between the leader and other characters is never allowed to develop. Not only Lawrence 
but also the whole family halts any progress of the discussion. The question posed in The Innocents is whether it is possible for a relative who had an affair with a married man, the husband of her cousin, to return to her family. The final answer is negative, but it has not been concluded as a result of a discussion between the havruta pair of Ellie and Adam, together with the elders of the family and with Lawrence, who should be identified as a metaphorical rabbi. Instead, the answer is imposed on Ellie and Adam by other participants of the potential, yet not realised, dialogue.

It is worth taking a closer look at the title of the novel. The term 'the innocents' may be extended to each character in the book, including Ellie and Adam. Although one of them has been expelled from the family, she is not guilty, as the title suggests. Perhaps her relatives would not decide to turn away from Ellie if they resolved to listen to her. Still, their behaviour is not a pointless act of psychological violence but rather an act defending a family and, more symbolically, a community striving to survive. If the title of the novel extends to all the characters, it may be argued that besides Ellie and Adam, Lawrence and the rest of the family are innocent as well. The relationship between a sexually liberated woman and Adam poses a threat to the structure of the family whose intentions, after all, had in view a noble purpose.

However, the novel indicates that a much more serious threat to the community is the omnipotence given to a leader who does not allow any space for dialogue. Lawrence only takes photographs that are meant to show a happy family but obviously, this is not the whole picture. It is very important to notice that the final paragraph of The Innocents is the already quoted description of the family reunion during the circumcision ritual. What the reader is left with after closing the book is an aura of intimidation, something absent from any other novel analyzed in this article.

\section{The regenerative power of discussion}

Amos $\mathrm{Oz}$ observed that "[p]erhaps (...) mainstream Orthodox Judaism had forgotten the spirit of questioning that the Talmud once knew" (Oz 2007b: 35). The basic premise of Judaism, which is the disputative manner of finding answers to substantial questions concerning lifestyle and religion has somehow evaporated both from Jewish families and synagogue communities. Contemporary British-Jewish writers seem to draw from the Talmudic method of study, some more and some less straightforwardly. For them, this tradition is not a constraint but a chance to work though intergenerational conflicts.

\section{References}

Alderman, Naomi. 2007. Disobedience. London: Penguin Books.

Arbor, Joy. 2014. "Shema Yisrael": Listening in Judaism and What It Has to Teach Us. In: M. Bernard-Donals and J. W. Fernheimer (eds.), Jewish Rhetorics: History, Theory, Practice, 198-214. Waltham, Massachusetts: Brandeis University Press.

Gilbert, Ruth. 2008. Contemporary British-Jewish writing: From Apology to Attitude. Literature Compass 5.2. 394-406. 
Jacobs, Louis. 2008a. The Babylonian Talmud: an introductory note. In: Louis Jacobs, Structure and Form in the Babylonian Talmud, 1-5. Cambridge: Cambridge University Press.

Jacobs, Louis. 2008b. How much of the Babylonian Talmud is pseudepigraphic? In: Louis Jacobs, Structure and Form in the Babylonian Talmud, 6-17. Cambridge: Cambridge University Press.

Mendelson, Charlotte 2007. When We Were Bad. New York: Houghton Mifflin Company.

Oz, Amos. 2007a. Preface. In: Amos Oz, Jews and Words, ix-x. New Haven: Yale University Press.

Oz, Amos. 2007b. Continuity. In: Amos Oz, Jews and Words, 1-56. New Haven: Yale University Press.

Salfati, Pierre-Henry. 2009. Talmud. Enquête dans un monde très secret. Paris: Éditions Albin Michel.

Schwartzer, Mitchell. 2001. The Architecture of Talmud. Journal of the Society of Architectural Historians 4.60. 474-487.

Segal, Francesca. 2013. The Innocents. London: Vintage Books. 